also with the fact that it was discovered in compact sandstone, instead of conglomerate. I shall be most happy to forward the specimen for the inspection of any one interested in the matter.

Junior Army and Navy Club.

H. W. Jamieson, Capt., F.R.G.S., Bengal Staff Corps.

\title{
NOTE ON MR. LEE'S SPECIMENS OF FOSSIL WOOD FROM GRIQUA LAND.
}

Sre,-The Lignite from Kimberly Mine, Claim 196, consists of stems, or branches converted into a brittle lignite, which still preserves the original size and form of the stems, and exhibits the internal structure peculiar to the Coniferm. The wood cells have a single series of discs, as in the wood of the recent Pines.

The specimens from Kimberly Mine, Claim 165, are more altered, and approach the condition of our Palæozoic coal. The small portions which show structure (mother-coal) consist of fragments of Coniferous wood, exhibiting the disciferous wood tissue with the discs in single rows.

The slides from the coal of Heilbron, Vaal River, Free State, consist of wood cells, with discs in single or double and opposite rows, as in the recent Pines.

W. Carruthers.

Botanical Department, British Museum.

GEOLOGY OF THE ISLE OF MAN.

SrR,-I examined in April, 1878, with Dr. Stolterfoth, of Chester, the Conglomerate of Langness in the Isle of Man, and can add my testimony to that of Mr. Morton (Geou. MaG., May, 1879), that Mr. Cumming was not mistaken in assigning them a position below the Carboniferous Limestone. Not only are they seen in the beach to dip under the Limestone, but the lower beds of the latter are themselves conglomeratic and interstratified with beds of red conglomerate, resembling those which occupy a large part of the promontory. Like Mr. Morton, I failed to find any limestone pebbles in the Conglomerates.

HOLYWELL, May 12, 1879.

A. Stratan.

[The following is a copy of a letter addressed to the Editor of the Times; published May 19th, 1879. Its contents are so important that we gladly take leave to reprint it in the Gkological Magazine.

-Edit. Grol. Mag.]

"Position of the Silurian Rocks in Herts.

"SIr,-In June. 1877, you did me the favour to insert in the Times the announcement and recognition by myself of the Devonian rocks in the deep boring at Messrs. Meux's Brewery, Tottenham-court-road, which there occurred below an abnormal condition of the Lower Greensand at the depth of 1,140ft. This announcement was at first received with doubt; nevertheless, the problem as to what was the nature of the Palæozoic rocks below London was there and then solved. Since then borings of greater diameter still have been put. down in other parts of the London Basin for the same purpose. 